\title{
Mezinárodní hudebněvědné kolokvium v Brně v období 1966-1976
}

\section{International Musicological Colloquium Brno in years 1966-1976}

Sofija Čolović / 381653@mail.muni.cz

Department of Musicology, Faculty of Arts, Masaryk University, Brno, CZ

\begin{abstract}
This paper is reflecting first ten years of the existence of International Musicological Colloquium in Brno from several different points of view. It describes circumstances of the beginning and development of close connected International Music Festival Brno and International Musicological Colloquium. Further, it observes thematic orientations of particular years of colloquiums. The paper also follows the structure of active participants of colloquiums, highlighting the proportion of musicologists coming from east and west countries of divided Europe.
\end{abstract}

\section{Keywords}

International Musicological Colloquium Brno, International Music Festival Brno, Leoš Janáček, Bohuslav Martinů, Hans Heinrich Eggebrecht, Carl Dahlhaus, Rudolf Pečman, Jiří Fukač, Miloš Štědroň 
Tento příspěvek reflektuje brněnská hudebněvědná kolokvia v první dekádě jejich existence, tj. v období 1966-1976, a to z několika různých pohledů, jako jsou otázky vzniku Mezinárodního hudebního festivalu Brno (dále jen $M H F B$ ) a muzikologického kolokvia, osobnosti a instituce, které u jejich zrodu stály a podílely se na jejich následujícím přetrvání. Dále se příspěvek věnuje tematickému zaměření jednotlivých ročníků kolokvií, zejména v souvislosti s tehdejší kulturně-společenskou situací a muzikologickým zájmem o jednotlivá témata. Dalším aspektem, který př́íspěvek zohledňuje, je i struktura návštěvníků, resp. aktivních účastníků kolokvií s ohledem na tehdejší kulturně-politickou situaci. Cílem je zjistit, zda v nově vzniknuvší politické situaci po obléhání Československa vojsky Varšavské smlouvy v srpnu 1968 a v následujících tzv. normalizačních letech došlo k redukci zahraničních návštěvníků.

Pro dosažení vytčených cílů se základním zdrojem staly sborníky příspěvků, které byly soustavně ke každému ročníku kolokvia vydávány. Dále bylo čerpáno i z dobových periodik, zejména z časopisu Hudebni rozhledy, ve kterém kromě recenzí na koncerty uskutečněné v rámci $M H F B$ byly, i když ne s takovou pravidelností, publikovány i zprávy o průběhu kolokvií. Relevantní publikací pro tuto práci se staly i paměti muzikologa Rudolfa Pečmana, který i přes řadu nejasností týkajících se sledovaného tématu poskytuje důležitá svědectví o okolnostech vzniku a průběhu brněnských festivalů a kolokvií, ale i všeobecné poznatky o hudebním životě v Brně minulého století.

\section{O vzniku a vývoji Mezinárodního hudebního festivalu v Brně}

Centrem festivalového hudebního dění v ČSR byla po celých dvacet let Praha, která svým mezinárodním festivalem Pražské jaro (1947) shromažd’ovala ty nejlepší interprety domácí a světové hudební scény. Tomuto festivalu začaly konkurovat teprve od roku 1965 pořádané Bratislavské hudobné slávnosti a o rok později i Brno svým $M H F B$.

Začátky festivalového dění v Brně byly téměř vždy spojeny s výročními oslavami skladatelských osobností - především Leoše Janáčka, k jehož př́ležitosti se v roce 1948 a zejména pak 1958 konaly široce zaměřené hudební slavnosti. V roce 1954 byl uspořádán festival v rámci Roku české hudby, pak v roce 1956 Festival Wolfganga Amadea Mozarta a rok nato i Beethovenův festival. I přes svůj význam pro hudební dění v Brně nebyly výše uvedené slavnosti pořádány kontinuálně, ale byly spíš ojedinělými událostmi. Prvním pravidelně se konajícím hudebním festivalem nejen v Brně, ale na celé Moravě byl Brněnský hudebni máj, který byl každoročně pořádán v období 1955-1965. Přesto, či právě proto, že vycházel ze vzorů a podnětů Pražského jara, nebyl po kvalitativní stránce schopen vymanit se z jeho stínu a byl vnímán jako pokus „zoufalých snah o prosazeni di̊stojnějšího repertoárového a interpretačního protikladu festivalu Pražské jaro, kterému se mohl ovšem jen přibližit. " man, který o festivalu ve svých pamětech napsal: „[...] Zjistili jsme, že je prece jen odvarem

1 ŠTĚDROŇ, Miloš. Konečně brněnský festival. Opus musicum, 1966, roč. 19, č. 9, s. 267. 
Pražského jara, nebot’ např́klad oni výkonni umělci, kteři hráli na festivalu v Praze, prijižděli za několik dnů do ,venkovského 'Brna s tímtéž programem. Brno mělo sice festival [...], ale bylo v okruhu programovém nesamostatné, nebot',pražské" programy byly jen opakovány v brněnském prostredi. "2 Dalším pravidelně pořádaným festivalem v Brně byl Celostátni festival sborového zpěvu (1956-1958), kterému bylo vyčítáno především to, že koncepčně působil spíš jako přehlídka pěveckých těles, často rozdílných úrovnî̉, než festival sledující určité dramaturgické záměry.

Myšlenka o uspořádání nového hudebního festivalu v Brně trvala několik let, než byl v roce 1965 odevzdán a pak Odborem kultury Národního výboru města Brna i schválen návrh organizace festivalu. Iniciátory vzniku nového hudebního festivalu byli zejména muzikolog Rudolf Pečman, který zajištoval dramaturgickou stránku festivalu, a Jaroslava Zapletalová, která měla na starosti stránku organizační. Tato dvojice byla zapojena i do organizace festivalu Brněnský hudebni máj, proto v jistém smyslu lze mluvit o návaznosti $M H F B$ na něj. Oproti Brněnskému hudebnímu máji přišel $M H F B$ se zcela novou dramaturgickou a festivalovou koncepcí, resp. se specifickým monotematickým zaměřením jednotlivých ročníků, což byl jeden ze zpo̊sobů, jak se vyhnout tehdy aktuálnímu, ale i dodnes často přetrvávajícímu sklonu festivalů upřednostňovat jednotlivé interprety před dramaturgickou koncepcí.

Monotematické řešení se i přes dramaturgické a organizační potíže, které s sebou nese, v případě brněnského hudebního festivalu stalo jeho největším kladem. I přestože byla programům jednotlivých ročníků festivalu ze strany kritiků často vyčítána neucelenost, resp. opomíjení „té či oné skladby, jež by zvlášt’ názorně dokumentovala dané téma“, či nedostatečné zastoupení hudby českých skladatelů, s každým nastupujícím ročníkem ukazoval festival svými uměleckými záměry svou životaschopnost.

Záměrem bylo vytvořit festival mezinárodního charakteru, lákající do Brna nejen zahraniční interprety, ale i širší hudební veřejnost, kritiky a odborníky z řad muzikologů a pedagogů. Proto byla k festivalovému dění hned od prvního ročníku $M H F B$ připojena řada akcí, z nichž se některé pořádaly jednorázově, některé však každoročně, a tím se staly neoddělitelnou součástí festivalu. Takovými jsou v první řadě každoročně pořádané Mezinárodní hudebněvědné kolokvium, Mezinárodní hudební soutěž Československého rozhlasu Prix musical de Radio Brno a Mezinárodni interpretačni soutěž.

Podobně jako festival a kolokvium, i rozhlasová soutěž hned od prvního ročníku vzbudila velký zájem nejen evropských, ale i světových rozhlasů. Za prvních deset let existence soutěže se jí zúčastnilo 35 rozhlasových stanic nebo společností z 22 států. ${ }^{5}$ Do tohoto počtu patří mimo jiné BBC, finský komorní rozhlasový sbor, rozhlasy z Rumunska, Polska, Mad’arska, Belgie, Moskvy, Švédska, Německa, ale i kanadský, novozélandský a australský rozhlas. Ideovým tvo̊rcem rozhlasové soutěže byl Zdeněk Cupák, tehdejší šéfredaktor

2 PEČMAN, Rudolf. Z hlubin paměti. Vzpominky muzikologa. Brno: Masarykova univerzita, 2007, s. 196. (dále jen PEC̆MAN)

3 BÁRTOVÁ, Jindra - ŠTĚDROŇ, Miloš. V brně se hrál Martinů. Hudebni rozhledy, 1966, roč. 20, č. 19, s. $622-623$.

4 FEM. Brno - festivalově, festival české hudby. Opus musicum, 1974, roč. 6, č. 10, s. 336-341.

5 NĚMEC, Václav. Prix musical de Radio Brno 1976. Opus musicum, 1976, roč. 8, č. 10, s. 297-300. 
pořadů artificiální hudby Československého rozhlasu. ${ }^{6}$ Předmětem soutěže byly rozhlasové pořady, jejichž témata se tematickému obsahu festivalu někdy blížila, někdy se však od něj pro specifické potřeby rozhlasu odkláněla. ${ }^{7}$

Na organizaci Mezinárodní interpretační soutěže se podílely Státní filharmonie Brno a JAMU. V rámci pětiletého cyklu se střídaly soutěže ve hře na varhany, kontrabas, lesní roh, tubu a bicí nástroje. V roce 2012 byla Mezinárodní interpretační soutěž sloučena s Mezinárodní soutěží Leoše Janáčka a funkci pořadatele převzala JAMU.

Pocitovaná potřeba a možnosti rozšířit festivalové dění města o další, tematicky jinak zaměřené hudební festivaly vedly v roce 1986 ke vzniku Expozice nové hudby a pak v roce 1991 ke vzniku Velikonočního festivalu duchovni hudby. MHFB se od roku 1993 pořádá pod názvem Moravský podzim, zatímco jeho původní název se stal označením pro organizační strukturu sdružující pod sebou všechny tři festivaly.

V prvních letech své existence byla organizace $M H F B$ přičleněna k tehdejšímu Parku kultury a oddechu, ${ }^{8}$ jehož koncertní oddělení vedla Jaroslava Zapletalová a které bylo jednou z nejdůležitějších institucí pro pořádání koncertů - počtem uváděných koncertů v některých sezonách převyšovalo dokonce SFB i brněnskou pobočku Svazu Československých skladatelů (dále jen SČS). ${ }^{9} \mathrm{~V}$ souvislosti se změnou politického systému, která se přímo odrazila ve změně způsobu financování festivalů, se pořadatelské funkce festivalů v letech 1993-2011 ujala specializovaná hudební agentura ARS/KONCERT. Tu v roce 2012 vystřídala Filharmonie Brno, která je dodnes výhradním organizátorem všech tří festivalů. Nejmladší z nich, Velikonočni festival duchovni hudby, jakož i Expozice nové hudby se konají každoročně, zatímco Moravský podzim se uskutečňuje jako bienále.

\section{Mezinárodní hudebněvědné kolokvium}

Idea propojení hudebního festivalu s odbornou muzikologickou reflexí daného tématu nebyla v Brně žádné novum. K realizaci této myšlenky došlo už v roce 1958, kdy byl k festivalu Leoš Janáček a soudobá hudba připojen mezinárodní hudebněvědný kongres.

Na tuto ideu pak navázal i $M H F B$, jehož organickou součástí se stalo Mezinárodní hudebněvědné kolokvium, které umožňovalo návštěvníkům festivalu, jak odborníkům, tak i běžným posluchačům, propojení znějící hudby s vědeckými - at' už teoretickými, historickými či jinak zaměřenými - výklady o ní.

6 ŠVECOVÁ, Natálie. Vývojové premeny dramaturgie Mezinárodniho hudebního festivalu Brno s prihliadnutím na Moravský podzim [online]. DP, FF, MU, Brno, 2013, s. 10. [cit. 25. 11. 2016] Dostupné z: http://is.muni.cz/ th/342204/ff_m/Dipl._praca.pdf.

7 CUPÁK, Zdeněk. Prix musical de Radio Brno 1972: VI. ročník mezinárodní hudební soutěže Československého rozhlasu. Opus musicum, 1972, roč. 4, s. 277-278.

8 PEČMAN, s. 198.

9 KARAFIÁT, Jan. Brněnské jaro 1968: K činnosti brněnské odbočky Svazu československých skladatelů mezi 4. sjezdem a rozpadem SČS [online]. DP, FF MU, Brno, 2011, s. 17. [cit. 25. 11. 2016]. Dostupné z: http://is.muni.cz/ th/178756/ff_m/Magisterska_diplomova_prace_-_Jan_Karafiat.pdf. 
Brněnská kolokvia rychle nabývala na svém významu a i přes každoročně narůstající počet účastníků si zachovala označení kolokvium, a to z toho důvodu, jak na úvodním setkání jednoho z nich naznačil Jiří Vysloužil, „že je na rozdíl od podobných mezinárodních muzikologických akcí pořádáme v komornějším rámci, který umožňuje přimý, bezprostředni osobni a pracovni kontakt všech účastniků. “Ale také proto, že hlavním smyslem těchto setkání byla a dosud je „vědecká výměna názorů pri uplatněni všech jejich charakteristických forem komunikace, jako jsou referáty, [...], vědecká sděleni [...] a také [...] věcné dotazy účastniků z pléna po každém jednotlivém vystoupeni $i$ diskuse $[\ldots]$ “...10

Význam brněnských kolokvií spočívá také v tom, že se mu i v období nepříznivých politických podmínek podařilo udržet kontinuitu. Jedinou výjimkou byl rok 1968, kdy v srpnu, jen několik týdnů před začátkem $M H F B$, bylo Československo okupováno vojsky Varšavské smlouvy. Na rozdíl od festivalu, jehož program byl během několik málo týdnů téměř celý změněn a i přes všechny potíže se konal v předem stanoveném termínu, konání naplánovaného muzikologického kolokvia se nakonec neuskutečnilo. Zatímco v případě festivalu byly zahraniční hosté odvoláni a nahrazeni domácími interprety u kolokvia k podobnému řešení nemohlo dojít. Jak už bylo zmíněno, vědecký přínos kolokviî spočíval právě v dialogu domácích a zahraničních muzikologů, a jelikož svou účast na kolokviu v roce 1968 potvrdilo 41 zahraničních a 12 domácích muzikologů, jeho úspěch byl přímo závislý na př́ítomnosti zahraničních hostů. Poněkud matoucí je vyjádření Rudolfa Pečmana v jeho pamětech, kde píše o událostech ze srpna 1968 a jejich následcích takto: „Kolokvium kupodivu zůstalo takřka nedotčeno, Jakobson a Brod odřekli, ale akce se konala za nevšedniho zájmu zahraniči." "11 Jde bezpochyby o omyl, což potvrzuje úvodní i závěrečné slovo sborníku příspěvků. Jako editor sborníku Pečman v závěru uvádí: „It contains studies and lectures that were to form the items of the contemplated colloquim, Leoš Janáček et Musica Europea; which ultimately did not take place. "12

Jak bude z následujícího výkladu zřejmé, brněnské kolokvium bylo jednou z mála př́íležitostí umožňujících setkání muzikologů z obou částí politicky rozdělené Evropy, a to i v období silných politických tlaků. Možnost kulturního ovlivňování představitelé režimu nevnímali nijak nadšeně. Kolokvium, jak Pečman vzpomíná, „zejména po nástupu tzv. normalizace 1970, bylo trnem v oku tehdejšim nohsledi̊m ze Státni bezpečnosti a z Ústředního výboru Komunistické strany Československa. "13

Brněnská kolokvia představovala tedy i jednu z mála možností domácích muzikologů vytvořit a udržet styky se zahraničními badateli, z nichž se některé později rozvinuly v bližší spolupráci.

10 VYSLOUŽIL, Jiří. Idea národnosti v moderní hudbě. In Idea národnosti a novodobá hudba. Colloquia musicologica. Brno: Mezinárodní hudební festival, 1973, s. 370.

11 PEČMAN, s. 124.

12 PEČMAN, Rudolf. In Leoš Janáček et musica europea. Colloquia musicologica. Brno: Mezinárodní hudební festival, 1968, s. 378 .

13 PEČMAN, Rudolf. Praeambulum aneb Brněnská muzikologie v době počátku a prvních vzmachů. In Musicologia Brunensis: Ad honorem Jan Racek, Bohumír Štědroň et Zdeněk Blažek 1905-2005: Sbornik př́spěvkỉ z mezinárodni hudebněvědné konference. Praha: Koniasch Latin Press, 2005, s. 27. 


\section{K organizaci hudebněvědného kolokvia v Brně}

V prvních dvou letech funkci předsedy kolokvia zastával Rudolf Pečman. Od roku 1968 se této funkce ujal Jiří Vysloužil, zatímco Pečman byl místopředsedou. Na organizaci se však podílela, at už aktivně, nebo jen podpůrně, i řada jiných jednotlivců a institucí.

Festival ani kolokvium by pochopitelně vůbec nemohly vzniknout bez podpory tehdejších státních orgánů. Kromě SČS, který byl takříkajíc prodlouženou rukou státu pro oblast hudebního umění, obě tyto akce v jistém smyslu podporovaly další městské a státní orgány, jako jsou Národní výbor města Brna, Jihomoravský národní výbor a Ministerstvo kultury ČSR.

Dále sem patří i Československá akademie věd a hudebněhistorické oddělení Moravského zemského muzea. V roce 1973 jak festival, tak kolokvium podpořila i Československá komise pro spolupráci s UNSECO.

Vzhledem k akademickému a pedagogickému zakotvení obou organizátorů kolokvia Rudolfa Pečmana a Jiřího Vysloužila se půda tehdejší Katedry dějin umění Univerzity J. E. Purkyně už od prvních ročníků kolokvia stala místem pro řešení mnoha organizačních otázek. Poté co se v roce 1990 kolokvium vymanilo ze závislosti na $M H F B$, a to jak po organizační stránce, tak i po stránce tematické, jeho organizace se oficiálně ujal Ústav hudební vědy, pod jehož záštitou se hudebněvědné kolokvium pořádá dodnes.

Jako konečný výsledek každoročních kolokviálních setkání byly vydávány sborníky příspěvků v rámci ediční rady Colloquia on the History and Theory of Music. Ty byly pokládány za velmi důležité a i přes velké potíže, občas i s několikaletým zpožděním, byly ke každému ročníku kolokvia vydány. Kromě nakladatelství $M H F B$ se na jejich přípravě se podílel i Český hudební fond. Dlouholetým editorem sborníků byl Rudolf Pečman (do roku 1986).

\section{Tematické zaměření kolokvií}

Tematické zaměření kolokvia v první dekádě jeho existence zpravidla úzce souviselo $\mathrm{s}$ tématem festivalu. V př́ípadě některých ročníků festivalu, jejichž téma bylo šířeji a volněji pojaté, bylo nutné téma kolokvia přizpůsobit čili tematicky specifikovat, a to s cílem dosáhnout jisté soudržnosti přednesených příspěvků a zabránit př́lišnému rozptýlení a nežádoucímu vzdalování se od tématu.

Mezi tématy, která se každoročně stávala předmětem diskusí ve vybraném období, jen stěží můžeme hledat nějakou pravidelnost či logiku. Vzhledem k mezinárodnímu charakteru bylo nutné volit téma přitažlivé jak pro domácí, tak i pro zahraniční badatele. Na druhé straně existovala snaha prezentovat na domácí půdě nejen českou hudbu jako takovou, ale i získané poznatky o ní, jichž se čeští badatelé dobrali. Cílem bylo dosáhnout širšího povědomí o české hudbě mezi zahraničními hosty a zároveň ji prezentovat v kontextu evropského hudebního dění. Mezi tématy kolokvií v sledovaném období si můžeme 
všimnout určité vyváženosti a téměř pravidelného stř́idání témat zaměřených na českou hudbu a témat celosvětového charakteru. Největší počet témat je časově nevymezený, dávající prostor hudbě všech historických epoch. Z časově vymezených témat však převažujî témata věnovaná hudbě 20 . století, která za deset let byla celkem třii, zatímco výhradně staré hudbě byl věnován jediný ročník.

Nelze jednoznačně rríci, která z oblastí hudební vědy byla nejvíce či nejméně zastoupena, a to z důvodu jejich častého překrývání. Každé z témat však bylo během kolokvií nahlédnuto a diskutováno z různých hledisek - historiografického, teoretického, metodologického, terminologického, sociologického ad.

Některá z témat byla však na svou dobu velice smělá. Vládnoucí režim nebyl před rokem 1968 nijak striktní, ovšem od šíření své ideologie neustupoval. Rozhodnutí věnovat první ročník festivalu dílu Bohuslava Martinů, který byl režimem marginalizován jak pro svůj kosmopolitismus a formalismus v hudbě, tak i pro své emigrantství, se proto jeví jako přinejmenším smělý krok. Bylo to, jak Pečman ve svých pamětech píše, „vlastně proti vưli vládnouci stranické garnitury “. ${ }^{14}$ První ročník kolokvia byl tedy věnován jevištní tvorbě Bohuslava Martinů. Některé př́íspěvky byly zaměřeny na jednotlivé skladatelovy opery, problematiku jejich dramaturgického uchopení a uvádění. Kromě toho se některé př́spěvky věnovaly i psychologickým aspektům oper Bohuslava Martinů.

Druhý ročník kolokvia nesl název Musica Antiqua a byl soustředěn na problematiku autentické interpretace staré hudby, což bylo téma v 60 . letech zcela aktuální. Příspěvky kolokvia lze tematicky rozdělit do dvou skupin. První z nich reflektovala problematiku historicky poučené interpretace vokální a instrumentální hudby 14. až 18. století, zatímco druhá část příspěvků byla věnována operní problematice.

$\mathrm{V}$ pořadí třetí ročník kolokvia měl proběhnout ve světle výročí úmrtí světově uznávaného brněnského skladatele Leoše Janáčka. Jak už bylo zmíněno, ke konání kolokvia v roce 1968 nakonec nedošlo. I přesto však byl vydán sborník př́spěvků, či přesněji řečeno studií vztahujících se $\mathrm{k}$ osobnosti a dílu Leoše Janáčka a jeho významu v kontextu evropské hudby 20. století. Najdeme v něm jednak studie reflektující různé aspekty jeho operní, orchestrální a komorní tvorby, jednak studie konfrontující skladatele s dalšími předními evropskými skladateli první poloviny 20. století.

Další ročník festivalu Musica Vocalis byl širšího zaměření, orientoval se na vokálně-instrumentální hudbu. Program byl sestaven z děl kantátových, oratorních, operních, písňových a mešních, přičemž konfrontoval hudbu barokní a současnou. Pro kolokvium byl vybrán tematický název Slovo a hudba, jenž měl široce zaměřené téma určitým způsobem omezit. Vztah slova a hudby byl reflektován v souvislosti s hudbou různých slohových epoch, od hudby renesanční po hudbu soudobou. Část kolokvia byla také věnována problematice hudební lexikografie. Mezinárodní setkání hudebních lexikografů, které se uskutečnilo v rámci kolokvia, v mnohém souviselo s plánovaným vznikem nového československého hudebního slovníku, který byl připravován na tehdejší Katedře hudební vědy. V rámci této lexikografické části kolokvia vystoupil mimo jiné i německý muzikolog

14 PEČMAN, Rudolf. Praeambulum aneb Brněnská muzikologie v době počátku a prvních vzmachů. In Musicologia Brunensis: Ad honorem Jan Racek, Bohumir Štědroň et Zdeněk Blažek 1905-2005: Sbornik př̌́spěvuku z mezinárodni hudebněvědné konference. Praha: KLP, 2005, s. 26. 
Hans Heinrich Eggebrecht, který své renomé hudebního lexikografa získal zejména jako editor věcné části Riemannova Musiklexikonu.

Jak naznačuje samotný název kolokvia v roce 1970 Musica Bohemica et Europaea, v centru pozornosti se opět nacházela česká hudba včetně svých vlivů, ohlasů a vztahů k hudbě evropské. Českou hudbou se muzikologové zabývali v širokém historickém měřítku od hudby pozdně gotického slohu po hudbu 20. století.

Do středu zájmu se v souvislosti s tematikou festivalu Musica cameralis v roce 1971 dostala komorní hudba. Takto široce uchopené téma umožnilo prostor pro nejrůzněji koncipované příspěvky. Komorní hudba česká a evropská byla zohledněna nejen z historického ale i z teoretického, sociologického, estetického a interpretačního hlediska. V rámci tzv. kulatých stolů se diskutovalo o terminologické a pojmoslovné problematice termínu komorní hudba.

Následoval festival s názvem Musicae Metamorphoses Saeculi Viginti a s ním související kolokvium Homo hodiernus musicam audit, které se oproti dosavadním kolokviím, orientovaným především hudebněhistoriograficky, zaměřilo spís na disciplíny systematické hudební vědy. Do středu zájmu se v roce 1972 poprvé dostala témata hudebněsociologického a hudebněpsychologického charakteru, týkající se především otázek procesu vnímaní a slyšení hudby. Některé z otázek, na které se kolokvium zaměřilo, se týkaly i společenských, psychologických, estetických, pedagogických a jiných předpokladů ovlivňujících konzumenta hudby a recepce hudby v různých společenských skupinách a systémech. Pozornost byla obrácena i k hudbě samotné, zejména k otázce, jak média, ekonomické, kulturní a další mechanismy ovlivňují nejen posluchače, ale i samotnou hudební produkci. Na kolokviu se tak poprvé objevilo místo i pro prezentaci výsledků bádaní a diskusi týkající se hudby nonartificiální.

Idea národnosti a novodobá hudba bylo téma dalšího ročníku. Toto rozmanité a různě uchopitelné téma, zasahující k oblasti společenské a kulturněpolitické, bylo na brněnském muzikologickém setkání soustředěno zejména na „hudebni kulturu Slovanu a ostatnich národů středni a jihovýchodni Evropy 19. a 20. stoleti" "15. Téma bylo opět pojato z několika různých hledisek - teoretického, metodologického a historického.

V roce 1974 se v souvislosti s celostátní oslavou jubilea Roku české hudby téma festivalu i kolokvia znovu obrátilo na domácí hudební tvorbu. Do středu zájmu kolokvia se dostaly disciplíny systematické hudební vědy. Zohledněna byla především problematika metodologická a hudebněhistoriografická. Kromě toho byly připomenuty i zakladatelské osobnosti české hudební vědy a jejich badatelský přínos.

Rok 1975 probíhal ve světle oslav výročí vítězství nad fašismem a ukončení 2 . světové války. Celosvětový trend sledoval svým tematickým zaměřením i MHFB. Kolokvium s názvem Hudba a dílo se tematicky zakotvilo v metodologických a gnozeologických otázkách z oblasti ideologie, sociologie a estetiky hudebního díla. Objevily se i příspěvky zasahující do oblastí hudební analýzy. Vstupní referáty, jen vzdáleně související se zvoleným tématem, reflektovaly vývoj české a slovenské hudební vědy v posledních 30 letech, tedy v období 1945-1975.

15 VYSLOUŽIL, Jiří. Idea národnosti v moderní hudbě. In Idea národnosti a novodobá hudba. Colloquia musicologica. Brno: Mezinárodní hudební festival, 1973, s. 371. 
V posledním ročníku námi sledovaného období se kolokvium vrací k tématu vztahu slova a hudby. Oproti kolokviu v roce 1969, kdy se jednotlivé prŕíspěvky týkaly vokální hudby především z hlediska historiografického a popisně-analytických řešení některých skladeb, toto kolokvium mělo za cíl „ukázat, jaký pokrok ukazuje muzikologie od roku 1969. “16 Byla zdůrazněna zejména „gnozeologická, sémiologická a teoretická, stejně jako estetická hledisk ${ }^{" 17}$ vokální hudby. Jednotlivé úseky kolokvia byly odvozeny od výše uvedených záměrů a diskuse o problematice vztahu slova a hudby probíhala na třech různých úrovních - první z nich definovala pojem vokální hudby, druhá směřovala $\mathrm{k}$ sémantickým a estetickým otázkám vokální hudby a třetí $\mathrm{k}$ teorii a historii vztahu hudby a slova.

\section{Struktura návštěvníků kolokvia v prvních 10 letech jeho existence}

Hned na začátku je nutné poznamenat, že první ročník jak kolokvia, tak i festivalu, který jsme si určili jako výchozí bod sledovaného období, jen stěží můžeme vůbec považovat za mezinárodní. Mezinárodní charakter festivalu se prakticky projevil zařazením jediného zahraničního orchestru - Katovické filharmonie pod vedením Karola Stryja. V případě kolokvia jej pak zajistili hned dva zahraniční muzikologové, Harry Halbreich z Bruselu a Viorel Cosma z Rumunska. Takto skromná účast cizinců nebyla však nijak podmíněna politickou situaci, ale byla spíš výsledkem toho, že šlo o první ročník festivalu, který svoji kvalitu musel teprve prokázat. Už v následujícím ročníku je zřejmý nárůst podílu zahraničních interpretů a muzikologů.

Jak už bylo zmíněno, v roce 1968 ke konání kolokvia nedošlo. Namísto řady př́spěvků a očekávaných diskusí, jež měly přispět k obohacení poznatků o osobnosti a dílu Leoše Janáčka a jeho evropských současníků, se na půdě brněnské univerzity uskutečnila pouze jedna přednáška, a to př́spěvek Waltera Salmena s názvem Die soziale Selbstverpflichtung von Komponisten seit dem 19. Jahrhundert. Toto vystoupení vyvolalo podnětnou diskusi, která jen nastínila, nakolik by bylo naplánované kolokvium podnětné, kdyby se uskutečnilo v plném rozsahu. ${ }^{18}$

V následujícím roce 1970 byl počet zahraničních účastníků ve sledovaném období vůbec nejvyšší. Kolokvia se aktivně zúčastnilo 35 domácích a 40 zahraničních muzikologů. Bylo to vůbec nejobsáhlejší kolokvium a zůstává otázkou, jak se účast tak velkého počtu přispívajících odrazila na kvalitě vědeckého setkání. Jelikož kolokvium zpravidla trvalo tři dny, je pravděpodobné, že program tohoto ročníku byl velice hutný. Otazník však zůstává nad vědeckým přínosem tohoto setkání, jelikož lze usuzovat, že prostoru pro diskusi mnoho nebylo. Daleko menší počet (do 40) přispívajících v následujících letech je pravděpodobně tahem organizátorů, který měl zabránit hrozbě, že se brněnské

16 ČERNÝ, Miroslav Karel. Slovo a hudba: IX. Mezinárodní hudebně vědné kolokvium v Brně. Hudebni rozhledy, 1976, roč. 29, č. 12, s. 565-567.

17 VYSLOUŽIL, Jiří. Vztah hudby a slova z teoretického a historického hlediska. In Wort Ton Beziehung vom theoretischen und historischen Aspekt. Colloquia Musicologica. Brno: Mezinárodní hudební festival, 1978.

18 VYSLOUŽIL, Jiř́i. In Leoš Janáček et Musica Europaea. Colloquia Musicologica. Brno, 1968, s. 19. 
kolokvium stane pouze setkáním, či spíše konferencí pro přednesení referátu a ztratí se kolokviální charakter setkání, na který byl kladen velký důraz. Tak velký rozdíl v počtu účastníků kolokvia nebyl tedy výsledkem žádných politických represí, ale krokem pro uchování vědecky přínosného charakteru setkání.

Omezení počtu přispívajících tím pádem zvyšovalo nejen kvalitu, ale v jistém smyslu i prestiž kolokvia. O tom kromě příspěvků ve vydaných sbornících svědčí i následující vyjádření Jiřího Vysloužila: „Dnes již nemůžeme pracovat živelně jako v prvnich letech, kdy jsme prijimali a víceméně paušálně zařazovali př́spěvky do tematicky skloubenich sekcí. V posledni době nabyla kolokvia na přitažlivosti; je proto třeba tento zájem regulovat a soustřed'ovat se předevšim na ty autory a př́spěvky, které slibuji jistý př́nos. " 19

Následující tabulka ukazuje počet domácích a zahraničních hostů za prvních deset let konání kolokvia.

\begin{tabular}{|l|c|c|c|}
\hline Rok & Počet domácích účastníků & $\begin{array}{c}\text { Počet zahraničních } \\
\text { účastníků }\end{array}$ & Celkový počet účastníků \\
\hline 1966 & 10 & 2 & 12 \\
\hline 1967 & 16 & 14 & 30 \\
\hline $1968^{20}$ & 11 & 25 & 36 \\
\hline 1969 & 16 & 11 & 27 \\
\hline 1970 & 35 & 40 & 75 \\
\hline 1971 & 12 & 25 & 37 \\
\hline 1972 & 12 & 25 & 37 \\
\hline 1973 & 15 & 16 & 31 \\
\hline 1974 & 21 & 18 & 39 \\
\hline 1975 & 8 & 17 & 25 \\
\hline 1976 & 11 & 23 & 34 \\
\hline
\end{tabular}

Kromě domácích muzikologů, kteří se kolokvií pochopitelně účastnili v největším počtu, se pravidelnými hosty stali rovněž badatelé téměř z celé Evropy. Největší účast na kolokviích v prvních 10 letech jeho existence bezpochyby prokázali badatelé z německy mluvících zemí, resp. z tehdy rozděleného Německa (odkud se kolokvia zúčastnilo celkem 49 muzikologů), Rakouska (12) a Švýcarska (7). Přestože bychom se mohli domnívat, že se z východní části Německa (Deutsche Demokratische Republik) kvůli nastolené politické situaci kolokvia účastnilo víc lidí než z německé západní části (Bundesrepublik Deutschland), čísla o tom vypovídají jinak. Počet účastníků je u obou německých zemí téměř stejný - z DDR navštívilo kolokvium 24 účastníků, z BRD jen nepatrně více, resp. 26 lidí. Vzhledem ke geografické blízkosti Rakouska, zejména však Vídně, se jako poněkud překvapující jeví malý počet účastníků z této země - celkem 11, z toho 7 z Vídně. Počty

19 VYSLOUŽIL, Jiří. Člověk vnímá hudbu, (S prof. dr. Jiřím Vysloužilem o př́inosu a perspektivách festivalových kolokvií). Opus musicum, 1972, roč. 4, č. 8-9, s. 275.

20 V roce 1968 ke konání kolokvia nedošlo. Jde pouze o poměr domácích a zahraničních studií, dochovaných ve sborníku příspěvku. 
návštěvníků z ostatních komunistickým režimem poznamenaných zemí jsou jen nepatrně odlišné. Nejvíce jich bylo z Ruska a Polska (po 11 účastnících z každé země), z Rumunska, Bulharska a Jugoslávie po 6 účastnících, z Mad’arska 3, z Lotyšska 2. Z dalších evropských zemí se kolokvia zúčastnili badatelé z Francie (2), Belgie (2), Nizozemska (2) a v dost větším počtu i muzikologové z Velké Británie (7). Ze skandinávských zemí vystoupili na kolokviu muzikologové z Dánska (2) a Finska (1). Není bez významu ani účast vídeňské muzikoložky Evy Badury-Skody, která kolokvium navštívila jako reprezentantka University ve Wisconsinu v USA, na níž působila.

Porovnáme-li počet účastníků ze zemí tzv. východního a západního bloku, dostaneme téměř shodná čísla. Z východoevropských zemí za prvních deset let navštívilo brněnské kolokvium celkem 61 muzikologů. Počet návštěvníků z kapitalistických zemí byl jen nepatrně vyšší - 68 badatelů. Porovnáme-li však počet příspěvků přednesených na kolokviu, uvidíme, že příspěvků z východních zemí bylo 113, zatímco ze Západu 110.

Mnohem větší rozdíl v návštěvnosti můžeme kupodivu sledovat mezi domácími účastníky kolokvií. Nepočítáme-li brněnské účastníky, z nichž mnozí patřili i k organizační radě kolokvia a každoročně na kolokviu referovali (J. Vysloužil, R. Pečman, J. Fukač, T. Straková, M. Štědroň ad.), uvidíme, že existuje velký rozdíl mezi počtem účastníků z Bratislavy a z Prahy. Za 10 let se kolokvia zúčastnilo celkem 10 muzikologů z Bratislavy (s celkem 15 prríspěvky), zatímco v případě jejich pražských kolegů je tento počet nepoměrně vyšší - 36 účastníků (65 příspěvků).

Za 10 let existence brněnského kolokvia se jej zúčastňovali nejvlivnější světoví odborníci z řad muzikologů, $\mathrm{z}$ nichž se někteří do Brna vraceli pravidelně. Z řady německých muzikologů jmenujme alespoň H. H. Eggebrechta, Carla Dahlhause, Hellmutha Christiana Wolfa, Lukase Richtera, Siegmunda Walthera Schulze, Martina Wehnerta, Ludwiga Finschera, Albrechta Riethmüllera a Waltera Salmena. Pravidelnými návštěvníky brněnských kolokvií byli dále i polská muzikoložka Zofia Lissa, Švýcar Kurt von Fischer a mnozí další. Výčet všech zúčastněných badatelů by byl zdlouhavý, proto se v následujícím výkladu zaměříme na ty, kteří se nějakým zpo̊sobem výrazněji zapojili do aktivit české hudební vědy a se kterými se domácím muzikologům podařilo navázat užší pracovní vztah.

Takovým případem byl H. H. Eggebrecht, německý muzikolog působící na Freiburské universitě, který byl v roce 1995 jmenován čestným doktorem Masarykovy univerzity. Jako znalec hudební terminologie a tvůrce lexikografických titulů spolupracoval Eggebrecht s brněnskou katedrou hudební vědy zejména na poli hudební lexikografie a „svými názory podstatně ovlivnil rozvoj Kabinetu pro hudebni lexikografii [...]. "21 Připomeňme jen, že Kabinet pro hudební lexikografii byl založen při dnešním Ústavu hudební vědy v roce 1966 a v jeho čele stáli Jiří Vysloužil a Jiří Fukač. Zajímavé je rovněž sledovat, jak Brno po vzoru svých učitelů navštěvovali i mladší muzikologové. Například z Eggebrechtových žáků se pravidelným hostem kolokvií stal Albrecht Rietmüller, dále jej navštěvovali i Petr Andraschke a Wolfgang Ruf.

21 PEČMAN, s. 126. 
Nebyl to výjimečný případ zdařilé spolupráce a navázání hlubších profesních styků. Podobně tomu bylo i v př́ípadě švýcarského muzikologa Kurta von Fischera a Jaromíra Černého. Na základě Černého př́íspěvku na kolokviu Musica Bohemica et Europaea v roce 1970 začal Fischer Černého „v dalšich letech všemožně podporovat a zprostředkoval ( $t$. osobně financoval) mu dokonce, hluboko v normalizačni éré, třitýdenni studijni pobyt na svém pracovišti, zahrnujici studia v Praze absolutně nedostupných pramenných edic a mikrofilmových kopii pramenư, umožňujici alespoň částečné vřazeni repertoáru z českých pramenů do př́islušných evropských souvislosti. "22

Někteří z účastníků kolokvia se sami badatelsky věnovali české hudbě. Takovým příkladem je Helmuth Christian Wolff, který se kromě dějin opery a hudební ikonografie zajímal i o českou hudbu, zejména Leoše Janáčka. Zúčastnil se kromě řady $M H F B$ a kolokvií také festivalových slavností a kongresu věnovaného Leoši Janáčkovi v roce 1958. Podobně brněnská muzikologie podnítila zájem Johna Tyrrella, anglického muzikologa patřícího dnes k nejvýznamnějším janáčkovským badatelům, kterému byl rovněž udělen čestný doktorát Masarykovy univerzity.

\section{Závěr}

Vznikem $M H F B$ a spolu s ním i mezinárodního hudebněvědného kolokvia získalo Brno významné postavení ve festivalovém dění nejen v kontextu celostátním, ale i evropském.

Kromě vědeckého přínosu kolokvií, který je nezpochybnitelný a o němž svědčí přinejmenším výběr aktuálních muzikologických témat, spočívá jejich význam z dnešního hlediska také v tom, že i v období silných politických represí zůstala vůči nim imunní. Brno se tak v období politicky a ideologicky rozdělené Evropy stalo jedinečným místem setkání muzikologů z obou stran železné opony a brněnská kolokvia, jak líčí Pečman, „oknem do svobodného světa“23.

\section{Bibliography}

BÁRTOVÁ, Jindra - ŠTĚDROŇ, Miloš. V brně se hrál Martinů. Hudebni rozhledy, 1966, roč. 20, č. 19 , s. 622-623.

CUPÁK, Zdeněk. Prix musical de radio Brno 1972: VI. ročník mezinárodní hudební soutěže Československého rozhlasu. Opus musicum, 1972, roč. 4, s. 277-278.

ČERNÝ, Miroslav Karel. Slovo a hudba: IX. Mezinárodní hudebně vědné kolokvium v Brně. Hudebni rozhledy, 1976, roč. 29, ̌̌. 12, s. 565-567.

FEM. Brno - festivalově, festival české hudby. Opus musicum, 1974, roč. 6, č. 10, s. 336-341.

22 GABRIELOVÁ, Jarmila. Brno 29. 1. 2005: tvưrčí spolupráce pražské a brněnské muzikologie. In Musicologia Brunensis: Ad honorem Jan Racek, Bohumír Štědroň et Zdeněk Blažek 1905-2005: Sbornik př́spěvků z mezinárodni hudebněvědné konference. Praha: KLP, 2005, s. 193.

23 PEČMAN, s. 136. 
FUKAČ, Jiří. V Brně poosmé - tentokrát se slovanskou tematikou. Opus musicum, 1973, roč. 5, č. 9, s. 276-287.

KARAFIÁT, Jan. Brněnské jaro 1968: K činnosti brněnské odbočky Svazu československých skladatelì mezí 4. Sjezdem a rozpadem SČS [online]. DP, FF MU, Brno, 2011, s. 17. [cit. 25. 11. 2016] Dostupné z: http://is.muni.cz/th/178756/ff_m/Magisterska_diplomova_prace_-_Jan_Karafiat.pdf

MACEK, Petr - PEČMAN, Rudolf (edd.). Musicologia Brunensis: Ad honorem Jan Racek, Bohumir Štědroň et Zdeněk Blažek 1905-2005: Sbornik př́spěvků z mezinárodni hudebněvědné konference. Praha: KLP, 2005.

MAJER, Jiří. Brněnský festival podeváté. In: HR, 1974, roč. 27, č. 12, s. 553-555.

NĚMEC, Václav. Prix musical de Radio Brno 1976. Opus musicum, 1976, roč. 8, č. 10, s. 297-300.

PEČMAN, Rudolf. Z hlubin paměti. Vzpominky muzikologa. Brno: Masarykova univerzita, 2007.

PEČMAN, Rudolf (ed.). The stage works of Bohuslav Martinů. Colloquia musicologica. Brno: Mezinárodní hudební festival, 1965.

PEČMAN, Rudolf (ed.). Leoš Janáček et Musica Europaea. Colloquia musicologica Brno: Mezinárodní hudební festival, 1966.

PEČMAN, Rudolf (ed.). Musica Antiqua. Colloquia musicologica. Brno: Mezinárodní hudební festival, 1967.

PEČMAN, Rudolf (ed.). Leoš Janáček et Musica Europaea. Colloquia musicologica Brno: Mezinárodní hudební festival, 1968.

PEČMAN, Rudolf (ed.). Music and Work. Colloquia musicologica. Brno: Mezinárodní hudební festival, 1969.

PEČMAN, Rudolf (ed.). Musica Bohemica et Europaea. Colloquia musicologica Brno: Mezinárodní hudební festival, 1970.

PEČMAN, Rudolf (ed.). Musica cameralis. Colloquia musicologica. Brno: Mezinárodní hudební festival, 1971.

PEČMAN, Rudolf (ed.). Homo hodiernus musicam audit. Colloquia musicologica. Brno: Mezinárodní hudební festival, 1972.

PEČMAN, Rudolf (ed.). Idea nationis et musica moderna. Colloquia musicologica. Brno: Mezinárodní hudební festival, 1973.

PEČMAN, Rudolf (ed.). Musica Bohemica. Colloquia musicologica. Brno: Mezinárodní hudební festival, 1974.

PEČMAN, Rudolf (ed.). The music work. Colloquia musicologica. Brno: Mezinárodní hudební festival, 1975.

PEČMAN, Rudolf (ed.). Wort-Ton-Beziehung vom theoretischen und historischen Aspekt. Colloquia musicologica. Brno: Mezinárodní hudební festival, 1976.

ŠTĚDROŇ, Miloš. Konečně brněnský festival. Opus musicum, 1966, roč. 19, č. 9, s. 267.

ŠVECOVÁ, Natálie. Vývojové premeny dramaturgie Mezinárodního hudebního festivalu Brno s prohliadnutím na Moravský podzim [online]. DP, FF, MU, Brno, 2013, s. 10. [cit. 25. 11. 2016] Dostupné z: http://is.muni.cz/th/342204/ff_m/Dipl._praca.pdf

VYSLOUŽIL, Jiří. Člověk vnímá hudbu, (S prof. dr. Jiřím Vysloužilem o přínosu a perspektivách festivalových kolokvií). Opus musicum, 1972, roč. 4, č. 8-9, s. 275.

VOJTĚCH, Ivan. Colloquium musica Bohemica et Europaea, Brno 28.-30. záŕí 1970. Hudebni rozhedy, 1970, roč. 23, č. 12, s. 569-570.

VOJTĚCH, Ivan. Colloquium musica cameralis, Brno 27.9.-29. 9. 1971. Hudebni rozhledy, 1971, roč. 24, č. 11, s. 491.

VOLEK, Tomislav. Brněnské kolokvium Homo hodiernus musicam audit. Hudebni rozhledy, 1972, roč. 25 , č. 11, s. 498-499. 
